\title{
Explaining the Fuel Protests ${ }^{1}$
}

\author{
Brian Doherty, Matthew Paterson, Alexandra Plows and \\ Derek Wall, \\ School of Politics, International Relations and the Environment, \\ Keele University, Keele, Staffs, UK, ST5 5BG
}

This is a pre-publication, post-peer-review version of the article which was published in the British Journal of Politics and International Relations, vol. 5, No. 1, pp.1-23. The definitive version is available at http://onlinelibrary.wiley.com/doi/10.1111/1467-856X.00093/abstract

\begin{abstract}
:
We describe and analyse the fuel protests in the UK in September and November 2000. We draw on theories of social movements to explain the success of the first of these protests and the failure of the second. We show how the loose, network forms of organisation contributed to the success in September, and the attempts to impose more formal organisations helped to cause the failure in November. We also show how the success of the protests depended on the articulation of the aims of the protestors with dominant social forces in British politics, in particular the oil companies, the police, and the mass media.
\end{abstract}

\begin{abstract}
Just how do you organise a picket, apparently with small numbers and overwhelmingly peaceful, and get the cooperation of the industry you target (like the powerful oil industry) - and the cooperation of the police, along with apparent widespread public support? Having done this, you virtually bring the nation to a standstill in a matter of days; you do not get arrested or beaten by riot police; and get to be number one news for days. You also get to dictate what goes in and out of your target industry and, while not actually physically stopping any trucks, you declare that your peaceful picket will prevent all but emergency service deliveries.
\end{abstract}

E-mail from an animal rights activist commenting on the fuel protests posted on closed e-mail list, 14 September 2000

In September 2000, a network of British farmers and road hauliers launched a dramatic campaign of direct action to protest at fuel duty. Their campaign followed a similar one by farmers, hauliers and fishermen in France, which had produced some concessions from the French government. The British protesters blockaded petrol refineries, starting with Stanlow in Cheshire, and within days created a fuel crisis that paralysed distribution and brought the country to a virtual halt. The media, politicians and the general public were astonished by the effectiveness of the fuel protest. Why did this protest have so much impact?

In addressing this question we will draw upon current approaches in the study of social movements. These suggest some common patterns in how protests usually develop. Despite the surprise effect of the fuel protests they followed a typical pattern, and the theories that explain how protests usually develop work well for this case. Social movement theory has provided a useful lexicon of concepts including networks, resources, repertoires, frames, activist trajectories and political opportunities for understanding the emergence of movements and the dynamics of protest events. Our intention is not so much to expand the body of theory, but to use it as a method of analysis. However, social movement theory has tended to arise out of analyses of either working class or 'new' social movements, typically leftprogressive in orientation, with which social movement theorists themselves have tended to

$1 \quad$ We are very grateful for the incisive and helpful comments of three anonymous reviewers for the BJPIR. Some of the research for this was funded as part of a grant from the ESRC's Democracy and Participation Programme. 
identify and sympathise. The fuel protests thus raise questions for social movement analysis, such as to what extent are social movement concepts developed for left-progressive movements generaliseable to the sectional interest groups such as farmers and hauliers who were the 'entrepreneurs' in these protests. We (the present authors) usually focus our attention on radical environmentalism and our sympathy with that movement informs our research. ${ }^{2}$ Our interest in the fuel protesters thus arises out of a concern for the challenge they pose to environmentalism. ${ }^{3}$ In this paper our focus is on how the protests worked. A fuller analysis of the causes of the protest would have to examine the role of the crisis of rural governance and the apparent decline in the influence of official representatives of farmers and hauliers (on the latter, see Robinson 2001).

We should emphasise that although we use social movement theory to understand the dynamics of the protests, we are not of the view that they themselves constitute a movement. Rather, they were two networks of activists which came together fairly opportunistically and were unable to sustain their collective activity for more than a short period. Nevertheless, social movement theory provides a set of tools for understanding the dynamics of protest events, and is in this sense that we use these theoretical tools. ${ }^{4}$

The first part of the paper summarises the main events in the September protests and their second phase in November. We examine why the September protests had such a major impact and why the second protest in November failed. We then draw on elements of social movement theory to explain this pattern of success and failure. But, we also emphasise that in addition to the forms of organisation, spontaneity of action, and so on, contributing to success, the fuel protests also succeeded because of the way their interests articulated with those of some dominant social forces in British politics. ${ }^{5}$

\section{The September and November protests}

The spark that ignited the protest was the action taken by around 150 farmers and hauliers from North Wales in September 2000. Discontent was particularly strong among livestock farmers, suffering the effects of the BSE crisis, falling livestock and milk prices and high fuel costs. Although duty on red diesel used for agricultural machinery and tractors is low compared to commercial diesel, the net price paid by farmers had increased from 14.9 pence per litre to 23.9 pence since May. Brynle Williams who became the leading figure among the North Wales farmers had not made a profit from his farm in four years. The more militant mood among farmers had led to the establishment of a network called Farmer's For Action

2 See for example Doherty (1999); Wall (1999); Seel and Plows (2000); Seel, Paterson and Doherty (2000). Doherty, Plows and Wall are currently engaged in an ESRC-funded research project on such movements.

3 It is not the focus of this paper, but we regard the implications for environmentalism as significantly more complex than a simplistic image of a populist reaction to the gains made by environmentalism. We deal with such complexities in another paper (Doherty, Paterson, Plows \& Wall 2001).

$4 \quad$ It is now widely recognised that social movement theory divides into three main bodies of thought, with three separate foci. Resource mobilization theory has been used primarily to explain the role of organizations in campaigning. New social movement theory is mainly concerned with the relationship between new political identities and structural changes in western society. Political process theory is concerned mainly with episodes of contentious politics, principally protests, but also riots and revolutions. Although all of these theories were developed to account for social movements, they all have broader application. Resource mobilization theory is concerned with collective action in general; new social movement theory with broader social change; and political process theory with all forms of protest and public contentious action, whether or not these are by an enduring social movement.

It is perhaps appropriate to emphasise that this paper has the obvious limitations of being written very close to the events. While we have engaged in some interviews, in particular with Brynle Williams, and one of us has good connections with some of the other North Wales farmers who were highly involved in starting the fuel protests, much of the assessments is based on newspaper material and commentaries from other sources such as e-mail discussion groups. 
(FFA), in March 2000, which claimed 7000 members at the time of the protests. A protest meeting of farmers was called at Ruthin cattle market on Monday September $4^{\text {th }}$ to coincide with an agricultural show at which many politicians would be present. ${ }^{6}$

Brynle Williams was disappointed with the low turnout and impact of the Ruthin meeting. Hauliers who had promised to come to the meeting had not shown up (Interview, 18 November 2000). He was therefore reluctant to agree when asked by a friend to chair a second meeting on Thursday September 7. He changed his mind when told that 'there's a lot of very angry hauliers out there'. The second meeting took place at St Asaph livestock market (close to Ruthin). This time there were around 200 farmers and hauliers present. By this point, the fuel blockades in France were a major news story. Those at St Asaph discussed what action they could take, including blockading the main road into North Wales, the A55. As Williams put it: 'Then someone said, what about Stanlow, and something just went click' (Interview with Williams, 18 November 2000). Williams spoke about his previous experience of protest against Irish beef imports at Holyhead in 1997 and warned the meeting that they would face the might of the state. Williams and others proposed the blockade to this meeting and a majority voted for it. Clive Swann, a farmer, recalled saying:

If we don't go now when we are motivated we'll wake up tomorrow morning saying 'It's Aunt Betty's wedding on Sunday and I cannot go'. There were some people who were nervous. They thought they might get hoovered up by the police.

(Quoted in The Guardian September 16, 2000)

It was agreed that the emergency services would still be able to get fuel and that the protest must remain non-violent. Brynle Williams said that no one would think any the worse of anyone who did not join the blockade, but it appears that they all went, despite some being reluctant. When they arrived at Stanlow Williams notes:

We didn't know anything about the place, when we got there we didn't even know what bloody gate it was [that they needed to blockade]...that's when these things [mobile phones] came in handy.

(Interview 18 November 2000)

\section{The Protest Spreads}

Other farmers and hauliers from the North-West of England soon joined the demonstration at Stanlow. The following day farmers and hauliers demonstrated at Pembroke oil refinery, Hemel Hempstead oil terminal and in Gateshead, while a slow convoy of 100 lorries and tractors caused tailbacks on the A1, producing a repeat of the images from France. By Saturday all the major oil refineries and depots in Wales and the North and West of England had been blockaded. By Monday $11^{\text {th }}$ September demonstrations at oil depots had spread to Scotland and the South of England.

The immediate impact of the protests was much deeper than the protestors or commentators anticipated. This was principally because they struck at a particularly vulnerable point of the economy, the oil distribution network, which had been organised along just-in-time delivery principles. This, combined with anticipated shortages by petrol consumers and thus panic buying, magnified the impact of the protests far beyond the expectations of the protestors.

Although there were some blockades, these were fairly small and short-lived. Blocking the road is illegal and at Stanlow the tractors and lorries were moved after six hours following negotiations because of concerns over fire safety. It was primarily the fact that tanker drivers were reluctant to cross the picket line that prevented deliveries being made. There was evidence of threats of intimidation of drivers, ${ }^{7}$ but little actual violence and only two arrests

\footnotetext{
$6 \quad$ Some at the Ruthin meeting were involved in FFA, although Williams was not a $m_{7}$ member.

7 Oil companies and the Trades Unions reported 183 cases of intimidation (Guardian October 26 2000), and these were taken seriously enough by Jack Straw to set up an elaborate set of mechanisms to prevent them reoccurring in November (Straw 2000). While it
} 
throughout the September demonstrations. It was probably the anticipation of what might follow rather than a reaction to cases of actual harm that explains the drivers' reluctance to take their tankers out. Moreover, oil companies took no action to protect drivers and some even tried to curry favour with the protesters by providing them with access to their canteens, toilets and car parks.

The Transport and General Workers Union (TGWU) played an important role in enabling the resumption of deliveries at Grangemouth in Scotland, which had stronger union organisation than other sites. Senior union officials persuaded drivers to go back to work at a five hour meeting during the night of Wednesday 13 September. They provided assurances about security, which included having two or three drivers in each cab and leaving together in a convoy.

This coincided with what was probably an independent decision by protesters at Stanlow to end their picket that night. ${ }^{8}$ The scale of the protests and their economic impact had far exceeded the expectations of the first blockaders and papers that had been supportive such as the Express and the Mail were calling for an end to the demonstrations. Protests were suspended with a sixty-day ultimatum to the government to make a major cut in fuel tax (of $26 \mathrm{p}$ per litre) or face a resumption of the protest.

\section{The Collapse of the Protests}

The second round of fuel protests was very different to the first. In addition to the simple factor of activist burnout, and practical difficulties due to extreme weather conditions, the lack of solidarity between the different groups involved in the initial protest was soon apparent. David Handley, Chairman of Farmers for Action, ${ }^{9}$ had attempted to create a new organisation based on the demonstrations at refineries. Frank Stears, a founder member of Transaction, the hauliers' protest organisation, had travelled to several sites as the September demonstrations came to an end and encouraged people to attend a meeting to create a new organisation. The People's Fuel Lobby (PFL) was formed by those who attended a meeting in Altrincham on September 19 (Times September 20, 2000)

However, the attempt to impose leadership on a set of networks lacking strong solidarity helped tensions to emerge as those who had not joined the PFL resented its claim to speak for fuel protesters. Brynle Williams attacked David Handley for planning actions that threatened to undermine the 60 day moratorium on protest. Handley responded by challenging Williams, saying: 'Who does he represent? I'm waiting for the man to come out and say who he represents' (Guardian October 26 2000). However, other North Wales farmers and Richard Haddock of FFA in the South-West said that they would not join the People's Fuel Convoy planned to coincide with the end of the 60 day deadline in November.

The protesters' network was loose and there had been little co-ordination between different protests sites in September. They lacked solidarity and a sense of common identity necessary to develop a common strategy. This was in part a consequence of the spontaneous development of the protest but, to a greater extent, it reflected the lack of common interests between farmers and hauliers. Although the PFL contained farmers, hauliers and private motorists, it did not represent many involved in the protests. Farmers began to complain that other issues in farming were being neglected in the concentration on fuel prices. Fuel was less important for farmers than for hauliers. Brynle Williams even expressed his support for

is necessary to maintain a certain critical distance from the absolute figures, given their sources, the number is large enough to imply that at least some intimidation occurred. $8 \quad$ Brynle Williams had been prepared to end it the previous morning, and had returned to his farm. He was brought back with the help of the police because he was seen as having the authority to ensure that the collective decision to end the picket would be upheld.

Although not central to our argument here, it is worth noting the male-domination of the leadership of the fuel protests. Women were not prominent in the main ranks of the protests, and much of the imagery and culture of the protesters was clearly masculinist, but the capacity of some of the farmers to engage in their actions was clearly dependent on women keeping their farms going. 
putting more freight onto rail, ${ }^{10}$ highlighting these differences in interests and outlook. They tended to see the fuel question as connected to the other issues around which they had previously mobilised (e.g. Irish beef imports). ${ }^{11}$

Handley and the PFL also made tactical mistakes. They planned to begin their convoy in Jarrow and make a symbolic link with the Jarrow Hunger March by unemployed in 1936. Yet, this was seen by many as an insulting comparison, leading the PFL to change its plans. They also made over-optimistic predictions about the numbers who might attend their rally in Hyde Park, suggesting figures around 500,000. Only a few thousand people had taken part in the September demonstrations and the PFL had little in the way of an infrastructure of local groups to organise transport. Thus, despite the strong support for lowering fuel taxes among the public, few were prepared to take action.

The Government's strategy was also important in defusing the second round of protests. By threatening to use the army to maintain fuel supplies, they signalled their determination. They used the crisis created by widespread floods and a safety crisis on the railways against the protesters, suggesting that more disruption would only create more misery.

Most importantly, the Chancellor made some concessions to hauliers, by cutting vehicle excise duty and making small cuts in fuel duty on diesel. This partial concession persuaded some hauliers to withdraw support for the November protests and also made the Government seem less arrogant. But, the concessions on fuel duty were very small and so did not contradict the previous defence of the importance of the revenue to public services.

The People's Fuel Convoy was small, with tens rather than hundreds of vehicles for much of the journey from the North East. The police controlled both the route and the speed of the convoy. Some environmentalists demonstrated against cuts in fuel taxes at various points on the route. While other convoys from Wales and the South West also joined the main convoy in London, they were prevented from driving into the city centre and the 500 or so protesters had to walk to Hyde Park.

\section{Explaining the protest's dynamics}

\section{Networks and Resources, Diffusion and Tactics}

A truism of social movement research is that protest rarely erupts from nowhere. From the comfortable distance of the front room television screen, action on the streets looks novel and unique. Yet, investigation often finds 'latent' networks of individuals and loose organisations that have been burrowing behind the scenes. Such networks are important for a number of reasons. First, numerous studies have found that previous involvement in an applicable political or social network is the most significant predisposing factor for activism in social movements (McAdam, McCarthy and Zald 1988; Marwell, Oliver and Prahl 1988; Walsh and Warland 1983, 765; Diani 1994, 88). Second, networks provide a means of communication, allowing political entrepreneurs to contact sympathisers (Freeman 1973; Granovetter 1973). Communication networks may aid resource mobilisation, accelerating donations not only of activists' discretionary time but finance, physical resources and repertoires. Third, affective

10 He did this in a debate on Radio Cymru on $17^{\text {th }}$ September. However, since this debate was in Welsh its significance was missed by the London media.

11 Ultimately, in terms of the origins of the protest for farmers, the fuel question only made sense as part of a more general crisis of the rural economy, particularly for sheep and cattle farmers. This crisis has had a complex set of origins, notably BSE, the CAP and its reform and a more general liberalisation of agricultural trade, the domination of suppliers by the big four supermarkets, the sense of a political onslaught on the countryside by New Labour (in which fox hunting has played a large part) and of course since the fuel protests the foot and mouth crisis. These have contributed to a drastic reduction in farm incomes in the late 1990s (MAFF 2000; O'Hagan 2001, 10-12, 35, 69), which have then simply been exacerbated by the large increase in fuel prices from 1999 onwards. For more detail on this aspect of the protests, see Doherty, Paterson, Plows and Wall 2001). 
ties make a difference between support and action. What makes the difference between the supporters of a cause who take action and those who do not is that those who act are likely to know someone who is already actively involved (McAdam 1986). Finally, 'weak ties' which provide bridges to very diverse networks, have been seen as more useful to the spread of protest than stronger ties to fewer groups (Granovetter 1973). As we will show, these different types of network ties were present at different stages of the fuel protests.

The decision to mount this protest was essentially spontaneous. By this we do not mean that it was irrational or instinctual action, but rather an on the spot decision, the consequences of which were unanticipated (Killian 1984, 779). Current social movement theory tends to overemphasise the strategic aspects of action at the expense of its spontaneity. Some who went to the meeting in St Asaph were prepared to take some kind of protest action, but the decisions to act immediately and to target the fuel depot were unplanned and unanticipated.

However, while the action taken by the Welsh farmers was spontaneous, there were also preexisting social networks, characterized by affective ties, that enabled them to take action and which also enabled the protest to spread. A sense of community provided the solidarity necessary for this action. Farmers and local hauliers who met regularly in buyers' co-ops and cattle markets did not want to let each other down, or would have been ashamed of not joining their neighbours. Networks based upon face-to-face contacts in which there are ties of mutual obligation and social pressure are a common factor underlying the emergence of new protest movements. The new political network helped the protest to spread. Farmers for Action used its regional contacts to mobilise support after the initial decision to act by North Wales farmers. But modern technology - in this instance the mobile phone rather than the internet - combined with informal networks also enabled quick mobilisation:

Mobile phones played a key part. Co-ordinating much of the protest was FFA chairman David Handley, and Williams. They ran an informal but effective 'bush telegraph'. Anyone they contacted had the numbers of a dozen other FFA supporters. And they would each have a dozen more. A single call could mobilise hundreds of people within an hour.

(Observer September 17, 2000)

Like the farmers, hauliers had also created their own loose organisation that served as a means for mobilisation. Transaction was formed at a meeting in Canterbury in April 1998 by Ron Wood and 20 other hauliers and truckers from Kent and Essex. By the time of the fuel protest, they claimed 1,200 members (Evening Standard September 14, 2000). This organisation represented smaller-scale haulage firms, dissatisfied with the weakness of the established Road Haulage Association. In addition, as was the case with the farmers the nature of the haulage industry meant that they had many contacts with fellow hauliers, a resource that enabled rapid communication and mobilisation. Haulier-farmers such as Tom Houghton and Paul Ashley from Sandbach were important in linking the networks of farmers and hauliers. The links between diverse local networks of farmers and hauliers were the kind of weak ties most conducive to spreading participation in protest.

Dramatic tactics, described as repertoires of contention or repertoires of action, are seen by social movement theorists as generally being borrowed and if necessary adapted from previous protest events. They are rarely, if ever, entirely novel (Tarrow 1998, 30) and they are made up of tactics already familiar to activists, derived from existing movements. In situations of relatively low-level conflict, protestors can play around with pre-existing tactics, so that they can feel secure in using them. This need to construct familiarity and to feel safe with a particular form of disruption is a reason why adaptation may be relatively slow. Yet, while adaptation is often seen as slow, in an increasingly globalised world the development of tactics is clearly accelerating and according to Tarrow (1998) innovation is key to movement success. Novel tactics can confuse opponents. Transference and adaptation may, at least in the short term, increase 'uncertainty' for opponents, yet, as repertoires become more familiar, opponents find them easier to 'normalise'. This analysis of tactics applies very well in explaining the nature of the action taken by the fuel protesters, although the success was less to do with the novelty of the tactics per se, but the novelty of the setting or target for those tactics, and the unfamiliar identity (for the police) of those engaging in these tactics. 
First, the protesters drew on the repertoire of French farmers made familiar by TV news and, for some, by direct contact with French farmers or hauliers. As Derek Mead, a wealthy Somerset farmer and housing developer, who chaired the meeting at which FFA was established, commented:

I know quite a few French farmers. Their union is far more in touch with everyday problems than the NFU, which is useless. They have a very tight network.

(The Guardian September12, 2000, 2)

However, this was not simply a case of copying the French. The two groups involved in the protest network had carried out separately a series of smaller scale and less successful protest actions since 1997. In 1997 farmers blockaded Holyhead in protest against the importing of Irish beef during the BSE crisis, dumping beefburgers into the sea. Farmers came from all over the country but the protest was organised from North Wales. Among those involved was Brynle Williams. Importantly, this protest had involved some confrontation with the police, and thus produced learning about how they deal with protest.

There were a number of other earlier actions through which farmers and hauliers each built (separate) networks and developed tactics. Actions against supermarkets were discussed at a North Wales farmer's meeting in 1998. In 1999 Williams and 44 other North Wales farmers protested at the low price of lamb by dumping 355 ewes at an RSPCA centre in North Wales. This action came after a further three calves were dumped in a telephone box in West Wales. After FFA was formed in 2000 there were 'pickets of supermarket distribution depots and dairies for much of the year in protest at the falling price of milk - down $50 \%$ in three years' (Guardian September 12, 2000).

Protests by hauliers against high fuel costs began with go-slows on the M6 in Birmingham and lorries from Kent stopping traffic in central London in June 1998. On 22 March 1999 (Daily Telegraph, March 23,1999) seven-hour closures to roads in London were organised by 'Trans-action' who rejected offers of talks with John Reid, Transport Minister. There was little interest in such protests on the part of the police or the British Government. The state was thus unfamiliar with the tactics and strategies of the fuel protesters, helping their success.

This review of previous protest tells an interesting story about diffusion and repertoires of contention. There were some contacts with France, but it seems most likely that it was images from France relayed through the media rather than personal contacts that explained the spread of fuel protests to Britain. It was North Wales farmers who took the initiative and made a spontaneous decision to blockade the oil refinery at Stanlow. This then inspired others who were already involved in farmers' and hauliers' protest networks to take action in their own localities. FFA and Transaction had used pickets, go-slows and blocking traffic with the tools of their trade for two years before the fuel protests. While the popular story was that this was the action of a group of 'ordinary' farmers and hauliers, as distinct from 'standard protesters', the reality, as social movement theory would have led us to expect, was that this was a group with an already existing repertoire of action. But, since these tactics were not in themselves especially innovative, we need to return to the questions posed by the animal rights activist in the epigram: What made protests so successful?

As the analysis above suggests, many of the core concepts developed by social movement theorists as tools to understand patterns of protest action can be successfully applied to the fuel protests. The role of informal networks, prior experience of action and the resources provided by workplace ties all help to explain how this protest was mobilised. Political opportunity structure models based on domestic factors seem to be of little help in explaining why these protests arose when they did. While domestic opportunities may be relevant to explain the initiation of protest in France, it was clearly French success that encouraged action in other countries. As Paul Ashley of FFA said:

We looked at the French and we thought enough is enough... We are just doing it the same as they are. We are heartened by the fact that their protests are having an effect. We have to make sure ours does too. 
('Blockade Tactics Cross the Channel', Guardian September 8, 2000)

This rapid spread of protest across Europe is perhaps the most remarkable feature of the fuel protests. While detailed examination of this question is beyond the scope of this paper, the common factors were the economic impact of rising oil prices, the role of truckers as the most common actors, and blocking roads as the most common form of action.

Nevertheless, the organisation of action in France differed considerably from Britain. In France existing formal organisations such as the farmers' union FNSEA, fishermen's unions, haulage federations (FNTR and Unostra) were joined by taxi drivers associations, driving schools, roadside recovery firms and private refuse contractors - some of who negotiated separately and directly with the government. This contrasts with the criticism of the NFU and Road Haulage Association in Britain by protesters who organised autonomously. Brynle Williams, who was an official in the Farmers Union of Wales (an organisation independent of the NFU), said:

I've spent the last five years in political lobbies not getting anywhere...this protest came about because no-one was listening...now I believe the doors are opening.

(Interview 18 November 2000)

This dissatisfaction with the weakness of 'insider' groups as a reason for establishing more radical networks, is similar to the dissatisfaction of many environmentalists with the compromises of groups such as Friends of the Earth (FoE) and Greenpeace. This latter dissatisfaction contributed to the emergence of environmental direct action in the early 1990s (Wall 1999; Doherty 1999; Seel and Plows 2000).

Another connection is the similarity in forms of action and organisation. Both fuel protesters and social movements of the left such as direct action environmentalists use direct action and both favour loose and decentralised networks rather than formally organised groups. A Guardian report on the fuel protests noted, ' "We don't have a designated leader because that's the best way to operate," said Tom Houghton, one of the militant 12, who rears cattle and sheep on 130 acres in Cheshire, and helped organise the picket which triggered Stanlow' (September 12, 2000). There were tactical reasons for this, which Richard Haddock (FFA organiser in the South West) acknowledged in a radio interview (Today Programme, Radio 4,29 September). Having no formal assets meant that injunctions against protest, which would have worked against the established groups, were useless against the new groups. However, unlike the radical environmental movement there was no ideological commitment to non-hierarchical practice. Formal leadership posts were established, even within loosely organised groups such as FFA and the People's Fuel Lobby, and this attempt to impose leadership on a set of activists with insufficient solidarity was one of the reasons for the infighting which contributed to the failure of the November protests.

\section{Conditions of Protest Success}

The apparent success of the fuel protesters was not only a result of the uncertainty they created. The key to their success was rather the way in which the positions they advanced could be articulated with the interests of dominant sections of British society. Sympathy and effective support from other actors provided useful opportunities. Of particular importance here were oil companies, the police and the media.

The interests of the oil companies in allowing protesters to succeed are fairly clear. While they may lose short term sales the longer term impact of reductions in fuel duty, or even simply preventing future increases in fuel duty, would be highly beneficial in terms of stimulating demand. The transnational nature of the oil companies meant they were in a good position to anticipate the protests. As some argued during the crisis:

During the petrol price protests, the [oil] companies had all had experience of refinery blockades in France the previous week, so were far better prepared than either protesters, police or government. It's not difficult to imagine an intranet dialogue between Jim Armstrong, manager of BP's Lavera refinery outside Marseille, Michel de Fabiani, head of BP France in Paris, Doug Ford, head of BP global refining \& 
marketing in London and Paul Maslin, manager of BP's refinery at Coryton in Essex over the weekend of 9 th - 10th September.

(Muttitt and Marriott 2000a).

The oil companies used the argument that drivers had been intimidated and they therefore allowed them to remain behind picket lines. Esso and Shell said that: 'Our information is that the drivers and terminal managers are currently not satisfied that there is a safe environment in which to continue operations.' (Financial Times, September 13, 2000). But at the same time, the oil companies also showed clear, if minor, material support for the protesters, belying perhaps their claims about intimidation, and at least providing evidence that they were happy for the protests to continue. A Financial Times report (September 13, 2000) noted how Shell had provided coffee to the protesters. Providing the demonstrators with coffee was a matter of good manners, said Edward Brady for Shell: 'The demonstrators say the argument is with the government and not with us. The fuel duty issue is not something we can do anything about. It can only be resolved by the government.'

It was clear that this tolerant approach to the protesters was the result of a conscious strategy by the oil companies. ${ }^{12}$ They decided that it was in their interests not to oppose the protests because they wanted to avoid drawing attention to themselves - both from the protesters and the public in general. Profits for oil companies were reported to be between 70 and $90 \%$ up on the previous year. (Observer October 29, 2000).

What is clear is that the oil companies put very little or no pressure on the police to enable them to prevent any intimidation by protesters which drivers experienced. ${ }^{13}$ There were accounts of the protesters sitting on oil company land, but no attempts were made to evict them, let alone invoke the 'aggravated trespass' offence created by the Criminal Justice Act of 1995. It was also clear from the hasty and heated meetings held with oil company executives that the government believed that oil companies were prepared to let the protests continue and used the intimidation of tanker drivers as a cover for their complicity.

Aside from embarrassment at their high profits, oil companies also feared that the Government might switch from taxing the consumer to taxing the producer. In 1993 the Conservative Government cut petroleum revenue tax from $75 \%$ to $50 \%$ for existing oil fields and abolished it for new fields (Muttitt and Marriott 2000). Revenue lost was recouped by taxing consumers. Duty paid at the pumps was increased by $10 \%$ and the fuel duty escalator established which increased prices by $3 \%$ above inflation each year thereafter, until it was abolished by the Labour Government in March 2000. The Chancellor of the Exchequer, Gordon Brown, had suggested reintroducing petroleum revenue tax in 1997, but was dissuaded from doing so by low prices for crude oil, combined with significant pressure from the oil companies (Muttitt and Marriott 2000). Yet, whereas the price per barrel in 1997 was $\$ 8$, by the time of the fuel protest it was over $\$ 30$.

The fuel protests can be seen in this context as in part an outcome of a contradiction within neoliberal political economy. The fuel tax rises from the early 1990s in the UK have their origins in the economic strategy of the UK state. This involved a fairly major restructuring of state finances away from income taxes (personal and corporate) to attract investment from transnational capital. It reflects the UK's financially dominant mode of insertion into the global

12 A source from the oil industry was quoted on the Today Programme (Radio 4) on October 192000 as saying that oil companies had met during the blockade to discuss a collective response. They had decided that it was not in their interests to oppose the protests - hence the slowness of resuming deliveries, and the hospitality offered to protesters. They wanted to avoid drawing attention to their high profits, both from protesters and from the public in general.

13 Even though many drivers were employed through sub-contractors rather than directly by the oil companies, the penalties for failure to deliver, which are routine in these outsourcing arrangements, could have been invoked by the oil companies if they had wanted to put pressure on the drivers or their immediate employers. 
capitalist economy ${ }^{14}$ as well as the increasing salience of 'globalisation' as a discourse informing state economic strategy, interpreted primarily in terms of increasing competition for a share of investment by highly mobile transnational capital. ${ }^{15}$ In the fuel case, this is represented by the removal of taxes on investment and production of oil, which were abandoned in 1993 by Norman Lamont in the same budget that the fuel duty escalator was introduced. The rises in fuel duty were thus primarily a matter of state finances, which then became a subject of contestation by the principal 'losers' of this economic strategy. Ironically of course, the agents whose investment in the UK economy were to be fostered by this economic strategy, the oil companies, ended up supporting the protests against the fiscal consequences of the strategy.

The policing of the protests also showed marked contrast to policing of structurally similar situations where police responses had been very different - notably strikes in the 1980s and perhaps even more so environmental direct action in the 1990s. The police showed considerable reluctance to arrest demonstrators (e.g. Financial Times, September 13, 2000). The protesters clearly believed that the police were very much on their side. Roy Masterson, a Cheshire-based haulier said:

Unfortunately for the government we are not committing a crime so they are trying to create a crime for us. There is no problem that requires special powers.

Everything has been peaceful and we've had co-operation from the police but they are under increasing pressure from the government to do something.

(Financial Times September 13, 2000)

The role of the police is perhaps less to do with the immediate class interests that explain the actions of the oil companies than with the cultural frames through which police tend to understand their own role and constitute the identities of protesters. Representations of normality and deviance are often key to police discourses that then influence their interpretations of particular events. As such, even though the actual situations may be structurally identical to, say, many elements of an anti-road protest, the interpretations of those events will have differed because of the way police interpreted key elements of law. What constitutes an action 'likely to cause a breach of the peace' for example will often depend fundamentally on how the police understand the identity of the protester. In this case ${ }^{16}$ the fuel protesters were understood widely by police as normal members of society with a particular grievance, ${ }^{17}$ rather than outsiders contesting society's basic norms (as they understand most anti-road protesters, for example) (della Porta 1998). ${ }^{18}$

14 For a brief overview of the debates about the financial dominance of the British economy, see Hay $(1999,165-7)$. See also generally Hutton (1995) and Elliott \& Atkinson (1999). The more immediate crisis which stimulated general tax rises was Britain being forced out of the ERM in September 1992 by financial speculators. This devaluation forced tax rises in general of \$17bn over 2 years in the 1993 budget (Hutton 1995, 76), including the increases in fuel duty. What is important here is to note that at a time of general tax rises, the taxes on oil production and exploration were in fact simultaneously being reduced, supporting our general claim about the restructuring of taxes to stimulate investment by transnationals.

15 On globalisation as political discourse in Britain, see Hay and Watson (1998). On the notion that globalisation has produced a shift to a 'competition state', see Cerny $(1990 ; 1997)$.

16 A similar case was the failure of police to take strong action against those who clearly broke the law in demonstrations against paedophiles at the Paulsgrove Estate in Portsmouth in August 2000.

$17 \quad$ This was confirmed in an interview with a senior policeman from the Greater Manchester Police.

${ }_{18} \quad$ The starkest contrast is with environmental direct action protests at refineries. Before the fuel protests, activists protesting about pollution and global warming blockaded Coryton refinery in Essex in March 1998, and were again swiftly arrested. See 'Chain Gang in Oil Plant Demo', Earth First! Action Update Online, no. 47, March 1998, at: http://www.ecoaction.org/efau/issues/1998/efau1998_03.html. Later, in September 2001, when animal rights activists co-ordinated by Manchester Animal Protection tried to block Stanlowe refinery in protest against Shell's connections to animal experimentation, 27 protesters were 
In addition to this cultural framing, the decentralised nature of British policing served to enable the protests in September to succeed. Police forces are not centrally organised and each regional police force has some autonomy in how it carries out its statutory role. Although the Home Office has authority over the police it does not exert central control over operational decisions. Thus despite his best efforts it was not possible for the Home Secretary Jack Straw to use the police to end the protests. The effect of police autonomy was also increased by the surprise nature of the protests. It took some time for the government to decide how to respond.

As the end of the 60-day ultimatum approached in November, the government and the police were able to present a more co-ordinated response, with the Home Secretary warning that truckers who blocked traffic would face the loss of their licence. The police also imposed conditions upon the convoy that travelled from Berwick to London, which greatly annoyed the protesters. ${ }^{19}$ Police cars ensured that the convoy travelled faster than protesters intended and motorway exits were blocked in order to control the route. Protesters were shocked that the police filmed protesters, although this is standard practice in policing demonstrations. Some police forces also banned the convoy from entering urban areas and the Metropolitan Police refused to allow them to enter London, citing the danger that blockades might provide a cover for a terrorist attack. By the time of the second protests the police and Home Office knew what the protesters would be doing, had been able to plan an effective response and were no longer relying on the discretion of officers taken by surprise by an unexpected protest by 'ordinary' people. ${ }^{20}$

Finally, the mass media also played a crucial role in the fuel protests. Their role was perhaps more contradictory. Throughout, the official editorial line in all the main tabloid papers (we looked in particular at the Mail, the Sun, the Mirror, and the Express) was that they supported the case for lower fuel duty (and in some cases had been vocally supporting it in their pages for months). However, they opposed direct action. Nevertheless, in a number of ways, the press and television helped to 'fuel the crisis' to use Roy Greenslade's phrase (Guardian September 18, 2000, G2, 1-3).

At the most immediate level, the media provided the medium through which knowledge of the protests was gained and could be spread, as already discussed. While in most of the 'blockades' outside refineries most protesters seem to have come together through their preexisting networks and channels of communication, there were also reports of people joining the protests after having heard of them from press or TV reports. ${ }^{21}$

Second, they articulated to the government (clearly caught off-guard, as already noted) widespread popular support for the protests and for the cause of reductions in fuel duty. The majority of the coverage throughout the peak of the crisis (11-15 Sept) produced a frame of the stoic struggle of ordinary folk in petrol queues, who, while frustrated, supported the

immediately arrested. See 'Shell Animal Testing Fuels Protest', The Loombreaker, no. 22, September 2001, also available at:

http://www.loombreaker.org.uk/loombreaker/022/loombreaker-022.html.

Co-ordination of this was not however perfect, with different police authorities imposing different conditions on the convoy. For instance, Greater Manchester Police refused to allow the convoy to travel slowly on motorways, or to travel through Manchester city centre, whereas other police forces did not impose such conditions.

20 In this sense the policing of the protests has a similar structure to that of strikes in the 1970s and 1980s. In the 1970s new forms of flying picketing emerged, notably in 1972 by the Yorkshire miners. The lack of central co-ordination of police strategy helped the strikers. By the early 1980s, the state had responded with new police co-ordinating mechanisms (as well as a criminalisation of secondary picketing) which enabled police to deal more effectively with similar occurrences notably in the miners strike of 1984-5. We are grateful to an anonymous reviewer for the BJPIR for emphasising this point to us.

21 Brynle Williams comments that many who joined the protest broadcast heard about it on Sky News: 'about two and a half-hours after the first broadcast people started arriving' (Interview 18 November). 
protesters and were hostile to the government's fuel tax policy. This reflects the humaninterest orientation of tabloids in particular, but also had the effect of creating a sense of massive popular support for the protests. This was then supported by their phone polls which all claimed overwhelming support (between $75 \%$ in the Mirror and $95 \%$ in the Mail) for the protests. While public support for the protests was an important factor in itself, comparison with other recent protests, suggests that the media's framing of the protests is more than simply a reflection of public opinion. A survey by ICM in October 2000 showed a surprisingly high level of support for anti-capitalist demonstrations; forty seven per cent of respondents said that 'street demonstrations against capitalism in London' and $42 \%$ that 'the demonstrations at the world trade talks in Seattle and Prague were 'perhaps' or 'definitely justified' ${ }^{22}$ Although these figures are much lower than the $74 \%$ who said that the UK 'petrol blockade' was either perhaps or definitely justified, the sympathy for anti-capitalist protests was much higher than the overwhelmingly negative reporting would have led us to expect.

Third, they created a construction of the protesters, which, while it varied according to political line (the Mirror is noticeably more hostile to the actual protesters, as opposed to public opinion on fuel tax, than the other papers), was, by and large, highly positive. The Mirror refers to them in one such piece as a 'ragbag' of demonstrators', engaged in 'wildcat action'. ('Blockade Brigade', September 13, 2000, 7). In the other papers, there is more of a 'middle England', 'typical British protest' construction. For example, The Sun has a list of 'All-time great British revolts: fuel blockage follows tradition of protest' (September 12, 2000, 8). This is the headline over a tour of protests since Boadicea. ${ }^{23}$ The Sun's first main piece on the protesters themselves is on 14th Sept (p6). The headline is 'Truth about demos: 'Militant as Teletubbies"'. In the context of allegations of intimidation, The Sun has a denial of violence by the protesters, and paints a picture of cooperation between protesters and oil tanker drivers. Essentially what occurs here is a reproduction of the hauliers/farmers self-presentation -'I'm not an anarchist ... just a simple farmer with big fuel bill' (Sun, September 15, 2000, 4).

A piece in the Mail by Glenda Cooper on September 13th (pp. 8-9) best exemplifies this construction. Entitled 'A very British blockade', this human-interest story on protesters is highly revealing. An explicit contrast is made with the Socialist Workers Party (SWP), the miners, and environmental direct activists. The focus is on their clothes ('immaculate chinos' or 'carefully pressed jeans, large sunglasses and polo shirt' as opposed to 'donkey jackets'), on their cars ('highly-polished Ford Galaxies and Renault Meganes'), and on class aspirations and family obligations (worries about funding putting children through university). It has many signifiers of class and nation. The piece opens '"The situation is awfully trying,' said the man wearing chinos. "But if one feels strongly about something, then something must be done. May I offer you a cup of tea?"'. The use of 'awfully', the use of the impersonal pronoun, the reference to tea, as in the Sun above, all create distinctive impressions of the protesters in terms of their class position and their essential 'Englishness'.

Yet, the press construction is a little more complex than this image suggests. In particular, it is influenced by the importance of state authority, especially to the traditionally Conservative press, and this limits the way that they can overtly support the protesters. Indeed, much of their coverage is devoted to how the protests provided a test for Blair's authority - for example his capacity to get the police to restore order, his capacity to cajole the oil companies and his capacity to ensure emergency services could operate effectively.

Nevertheless, the dominant effect of the media was to create legitimacy for the protests and their cause. There are a number of elements which helped to contribute to this dominant

22 We are grateful to Patrick Dunleavy for providing us with this information. The poll was carried out for the Joseph Rowntree Reform Trust and published in the Sunday Times. For full results see: www.sunday-times.co.uk/news/pages/sti/2000/11/12/stateofnation2.html. ${ }_{23}$ But only the day before, when most of the attention was still on protests in France, its editorial had directly opposed the protests as being 'un-British' - saying: 'The French have been "revolting" for centuries. The Sun does not want to see this kind of secondary picketing -for that is what it is - In Britain.' (The Sun September 11, p.8) Secondary picketing is missing from The Sun's pocket history of protest on the next day, as are most instances of labour movement protest. 
frame. The political economy of the press, in particular its reliance of the press on advertising, much of which is from car manufacturers, and the more general identification of their interests with the success of a capitalist economy because of their ownership patterns, provides part of the explanation. There is also a cultural politics to the press, with their construction of a relationship of identification between themselves and their readership (in the case of the Mail and the Express understood as politically on the centre-right), and their self-understanding as playing a normalising effect, reproducing the normative elements required for a stable national life.

This ideological effect, combined with the practical support given by policing cultures and oil company collusion, helped to create conditions where the fuel protests could succeed. What was key here therefore is the articulation of their interests and aims within a broader social structure. This should not be understood as a conspiracy, a set of deliberately co-ordinated actions by these various actors. Nor are the interests of these various interests neatly coincident. The media attacks the oil companies for their price hikes late on in the protests, and constructs them as complicit and greedy when they meet with Blair. The haulage protesters also see the oil companies in other contexts as being opposed to their interests. So, this is clearly an event containing many internal contradictions. Nevertheless, the capacity of the protesters to garner support from powerful elements of society is clearly a distinct and fundamental difference to the processes of environmental direct action protest.

\section{Conclusions}

We have tried to explain the impact of the fuel protests in terms of several complementary factors: the surprise effect of direct action and its rapid spread; the loose, network organisation of the protests in particular in September; the enabling of the protest by the oil companies; the initially soft policing; and the sympathetic framing of the protests by the media. To these political factors we can add a psychological and an economic factor. First, panic-buying by motorists led petrol stations to run out of fuel very rapidly and this greatly increased the impact of the demonstrations. Second, just-in-time delivery systems and the concentration of oil storage at relatively few sites meant that supply chains were vulnerable to the actions of a relatively small number of protesters. Those who took the initiative at Stanlow were knowledgeable about supply chains and clearly anticipated this effect, once they had decided to target the refinery, though they may not have anticipated that its scale would become so significant.

Disruptive and confrontational protest is now a regular and normal part of British political life. Even illegal protests pursuing very different goals gain widespread public support. ${ }^{24}$ In these circumstances even when the numbers taking part in protests remain small, their impact can be significant, particularly when, as was the case with the fuel protests, their interests articulate with dominant interests in British society. Their greatest impact therefore, was in the disruption they caused and the sudden collapse of support for the government in opinion polls, the greatest since the 1992 exit from the ERM and the 1979 Winter of Discontent (Crewe 2001: 80). While the government quickly recovered ground, the crisis helped to reinforce the sense that the metropolitan elite was out of touch with the concerns of rural Britain. As we have shown, poor tactics and a lack of solidarity, meant that the protesters were unable to win major concessions from government and, in that sense, their impact was more limited. Their political impact may be greatest in making governments more cautious about using indirect taxation. Culturally, they provide further evidence of what Tarrow (1998) calls the emergence of a movement society, in which non-violent protest has become a normal feature of political participation for very diverse social groups.

\section{Bibliography}

$24 \quad$ For instance, $55 \%$ of respondents in the ICM poll quoted above (FN 20) viewed the destruction of genetically modified crops as perhaps or definitely justified, the same proportion also viewed Countryside Alliance and pro-hunting demonstrations as definitely or perhaps justified. 
Cerny, Phil (1990) The Changing Architecture of Politics (London: Sage).

Cerny, Philip G (1997) 'Paradoxes of the competition state: The dynamics of political

globalization', Government \& Opposition, 32: 2, 251-75.

Crewe, Ivor (2001) 'Election and Public Opinion' in Seldon, A. (ed.) The Blair Effect, London:

Little, Brown and Co.

Della Porta, Donatella. (ed.) (1998), Policing Protest (London: UCL Press).

Diani, Mario. (1994), Green Networks (Edinburgh: Edinburgh University Press).

Doherty, Brian (1999) 'Paving the Way: the Rise of Direct Action against Road-building and the Changing Character of British Environmentalism', Political Studies, 47:2, 275-291.

Doherty, Brian, Paterson, Matthew, Plows, Alexandra and Wall, Derek (2001) 'Farmers, truckers and Greens: complicating the implications of the fuel protests', unpublished paper, Keele University.

Elliott, Larry and Atkinson, Dan (1999) The age of insecurity (London: Verso).

Freeman, J. (1980), Social Movements of the Sixties and Seventies (New York, NY: Longmans).

Granovetter, M. (1973), 'The strength of weak ties: A network theory revisited', American Journal of Sociology, 78:1, 481-510.

Hay, Colin (1999) The political economy of New Labour (Manchester: Manchester University Press).

Hay, Colin \& Watson, Matthew (1998) Rendering the Contingent Necessary: New Labour's Neo-Liberal Conversion and the Discourse of Globalisation (Center for European Studies' Program for the Study of Germany and Europe, Working Paper no 8.4, Cambridge MA: Harvard University).

Hutton, Will (1995) The State We're In (London: Jonathan Cape).

Killian, Lewis .M. (1984) 'Organization, Rationality and Spontaneity in the Civil Rights Movement, American Sociological Review, 49, 770-783.

MAFF (2000) Forecast on farm incomes, MAFF Statistical Notice SCF[04/00] 30 November 2000 (London: MAFF).

Marwell, G. Oliver, P. and Prahl, R. (1988) 'Social networks and collective action' American Journal of Sociology 80: 2, 402-42.

McAdam, Doug. (1986), 'Recruitment to high-risk activism: the case of Freedom Summer', American Journal of Sociology, 92, 64-90.

McAdam, Doug. McCarthy, John. and Zald, Mayer. (1988), 'Social Movements' in Smelser, N. (ed) Handbook of Sociology (Beverly Hills, Ca: Sage).

Muttitt, Greg and Marriott, James (2000) 'Pump and circumstance', The Guardian, October 4, 2000, G2, 9.

Muttitt, Greg and Marriott, James (2000a) 'Fuel Facts', Corporate Watch, Issue 12, Autumn.

O'Hagan, Andrew (2001) The End of British Farming (London: Profile Books).

Robinson, Nick (2001) 'The politics of the fuel protests: towards a multi-dimensional explanation', paper at the ECPR General Conference, University of Kent.

Seel, Benjamin, Paterson, Matthew, and Doherty, Brian (eds) (2000) Direct Action In British Environmentalism (London: Routledge).

Seel, Benjamin and Plows, Alex (2000), 'Coming Live and Direct: Strategies of Earth First!', in Seel, Paterson and Doherty (2000), 112-132.

Straw, Jack (2000) Statement by the Home Secretary to the House of Commons, Thursday 2 November, as reproduced at http://www.guardianunlimited.co.uk/petrol/story/.

Tarrow, Sidney. (1998), Power in Movement (London: Cambridge University Press).

Wall, Derek (1999) Earth First! and the anti-roads movement (London: Routledge).

Walsh, E. and Warland, R. (1983) 'Social Movement Involvement in the Wake of a Nuclear Accident:: activists and free riders in the Three Mile Island Area' American Sociological Review, 48, 764-80. 